\title{
Cip/Kip proteins: more than just CDKs inhibitors
}

\author{
Catherine Denicourt and Steven F. Dowdy ${ }^{1}$
}

Howard Hughes Medical Institute, and Department of Cellular and Molecular Medicine, University of California San Diego School of Medicine, La Jolla, California 92093-0686, USA

Members of the Cip/Kip family of cyclin-dependent kinases inhibitors (CKIs) are well characterized for their role as negative regulators of $\mathrm{G}_{1}$-phase cell-cycle progression (Sherr and Roberts 1999). In eukaryotic cells, progression through the cell cycle is governed by a suite of cyclins and cyclin-dependent kinase (CDKs) complexes (Murray 2004). Regulation of cyclin-CDKs complexes occurs at multiple levels, including assembly of cyclin and CDK subunits, inhibitory and activating phosphorylation and dephosphorylation events, and association of cyclin-CDK complexes with CKIs. During these regulatory processes, cyclin-CDK complexes positively drive progression of the cell cycle, whereas by binding to and inactivating cyclin-CDKs, CKIs negatively regulate progression through the cell cycle. Based on their sequence homology and specificity of action, CKIs are divided into two distinct families: INK4 and Cip/Kip (Sherr and Roberts 1999). Members of the INK4 family, namely p15, p16, p18, and p19 specifically inhibit the activity of CDK4 and CDK6, whereas Cip/Kip members, that is, p21, p27, and p57 inhibit a broader spectrum of cyclinCDK complexes (el-Deiry et al. 1993; Gu et al. 1993; Harper et al. 1993; Polyak et al. 1994; Toyoshima and Hunter 1994; Lee et al. 1995).

Until recently, Cip/Kip members were almost solely viewed as nuclear proteins with a principal function of inhibiting cyclin-CDK activity and hence, cell-cycle progression. However, emerging studies now suggest that Cip/Kip proteins play additional roles outside of the nucleus (Coqueret 2003). Indeed, previous reports have linked $\mathrm{p} 27^{\mathrm{kip} 1}$ to the regulation of actin dynamics and cell migration (Nagahara et al. 1998; McAllister et al. 2003). Moreover, several recent papers have shown that $\mathrm{p} 21^{\text {cip } 1}$ can act as a Rho-kinase (ROCK) inhibitor and that $\mathrm{p} 57^{\mathrm{kip} 2}$ modulates subcellular localization of LIMK, a serine/threonine kinase involved in the regulation of actin filaments (Tanaka et al. 2002; Yokoo et al. 2003; Lee and Helfman 2004). In this issue of Genes \& Development, a report by Besson et al. (2004) shows that cytoplasmic $27^{\text {kip } 1}$ modulates actin dynamics by direct regulation of the small GTPase RhoA pathway.

\footnotetext{
${ }^{1}$ Corresponding author.
}

E-MAIL sdowdy@ucsd.edu; FAX (858) 534-7797.

Article and publication are at http://www.genesdev.org/cgi/doi/10.1101/ gad.1205304. p2 $7^{\text {kip } 1}$ was originally identified as an inhibitor of cyclin-CDK complexes in cells arrested by transforming growth factor-beta (TGF- $\beta$; Polyak et al. 1994; Slingerland et al. 1994). Forced expression of $\mathrm{p} 27^{\mathrm{kip} 1}$ results in a $\mathrm{G}_{1}$ phase cell-cycle arrest in most cell types by associating with complexes of cyclins D1-D3:CDK4 or CDK6 and cyclin E or cyclin A:CDK2 (Polyak et al. 1994; Toyoshima and Hunter 1994). Growth arrest by contact inhibition is also thought to be mediated in part by p2 $7^{\text {kip } 1}$ (Polyak et al. 1994). In normal cells, p2 $7^{\text {kip } 1}$ protein levels are highest during $G_{0}$ and early $G_{1}$ phases, then rapidly decline in late $G_{1}$ and $S$ phases (Nourse et al. 1994; Reynisdottir et al. 1995). p2 $7^{\text {kip1 }}$ abundance is primarily controlled by phosphorylation-regulated ubiquitin-mediated proteolysis (Pagano et al. 1995). Phosphorylation of $\mathrm{p} 27^{\text {kip } 1}$ on Thr-187 by CDK2 allows for $\mathrm{SCF}^{\text {Skp2 }}$ ubiquitin-protein ligase recognition and subsequent degradation (Carrano et al. 1999; Sutterluty et al. 1999; Tsvetkov et al. 1999). p2 $7^{\text {kip1 }}$ harbors its cyclin-CDK inhibition and binding in an $\mathrm{N}$-terminal domain that contacts both the cyclin and the CDK subunits (Russo et al. 1996). Importantly, to exert its CDK inhibitory functions, $\mathrm{p} 27^{\mathrm{kip} 1}$ is required to be localized in the nucleus. p2 $7^{\text {kip } 1}$ contains a phosphorylation-regulated nuclear localization signal (NLS) harbored in the C terminus (Zeng et al. 2000). Transport of $\mathrm{p} 27^{\text {kip } 1}$ between the nucleus and the cytoplasm is also regulated by phosphorylation events. Upon mitogen stimulation, the human kinase interacting stathmin (hKIS) phosphorylates p2 $7^{\text {kipl }}$ on Ser 10 to signal its nuclear export into the cytoplasm (Ishida et al. 2000; Rodier et al. 2001; Boehm et al. 2002). Furthermore, phosphorylation of $\mathrm{p} 27^{\mathrm{kip} 1}$ on the NLS Thr-157 by AKT disables its nuclear localization capacity (Liang et al. 2002; Shin et al. 2002; Viglietto et al. 2002). Thus, nuclear binding of cyclin-CDK complexes appears to account for most or all of the previously associated properties of $\mathrm{p} 27^{\mathrm{kip} 1}$ in negative regulation of cell-cycle progression.

However, emerging data have suggested a role for cytoplasmic $27^{\text {kipl }}$ in the regulation of cell migration independent of cyclin-CDK inhibition. Nagahara et al. (1998) first demonstrated that delivery of a transducible form of p2 $7^{\text {kip1 }}$ (TAT- p2 $7^{\text {kip } 1}$ ) into HepG2 hepatocellular carcinoma cells induced cell migration or scattering to a similar extent as HGF. Subsequent work found that 


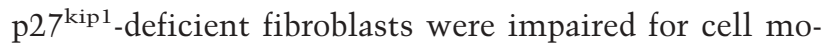
tility and that reconstitution of $\mathrm{p} 27^{\mathrm{kip} 1}$ protein rescued the cell migration defect (McAllister et al. 2003). The ability of $27^{\mathrm{kip} 1}$ to induce cell migration resides in a C-terminal "scatter domain" that has a loose sequence similarity with the yeast cell-cycle inhibitor homolog Farlp, which is also involved in actin rearrangement (McAllister et al. 2003). Loss or disruption of the C-terminal p $27^{\mathrm{kip} 1}$ scatter domain abolished both actin rearrangement and cell scattering independent of cyclinCdk binding or inhibition. Importantly, phosphorylation of $27^{\text {kip } 1}$ on Ser 10 is necessary for both cytoplasmic localization and induction of cell migration. These observations solidified a genetic role for $\mathrm{p} 27^{\mathrm{kip} 1}$ in cell migration that is independent of cyclin-CDK inhibition. However, exactly how and through which pathway p $27^{\text {kip } 1}$ mediates this process remained unresolved.

Besson et al. (2004) now shed light on how p27 kip1 regulates actin dynamics to promote cell migration. Building on the observation that $\mathrm{p} 27^{\mathrm{kip} 1}$-deficient fibroblasts have decreased motility, they first observed that p2 $7^{\mathrm{kip} 1}$-deficient cells displayed an increased amount of stress fibers and focal adhesions compared to wild-type cells. The addition of PDGF to MEFs normally induces rearrangements of focal adhesion and actin stress fibers, accompanied by formation of membrane ruffles and lamellipodia. However, treatment of p2 $7^{\mathrm{kip} 1}$-deficient cells failed to induce these actin-associated rearrangements. Reintroduction of either a wild-type $\mathrm{p} 27^{\mathrm{kip} 1}$ or a p $27^{\text {kip } 1}$ mutant with impaired binding to cyclin-CDKs into p2 $7^{\mathrm{kip} 1}$-deficient cells significantly decreased both the number of stress fibers and focal adhesions. These observations suggested that $\mathrm{p} 27^{\mathrm{kip} 1}$ was regulating actin dynamics necessary for cell migration independent of cyclin-CDKs complexes.

Members of the Rho family of small GTPases are important regulators of cell motility involving the actin cytoskeleton (Moon and Zheng 2003; Fig. 1). RhoA and its effector ROCK (also known as Rho kinase) are well characterized for their role in mediating the formation of stress fibers and focal adhesions (Riento and Ridley 2003). GTP-bound, active RhoA stimulates ROCK, which phosphorylates and activates LIMK, a serine/ threonine kinase also involved in the regulation of actin filaments dynamics. LIMK phosphorylation of cofilin, an actin-depolymerizing protein that regulates actin filament turnover, inhibits its actin-depolymerizing activity. Building on their actin dynamics clue, Besson et al. (2004) then went on to analyze the level of RhoA activity in the p $27^{\mathrm{kip} 1}$-deficient cells. Surprisingly, compared to

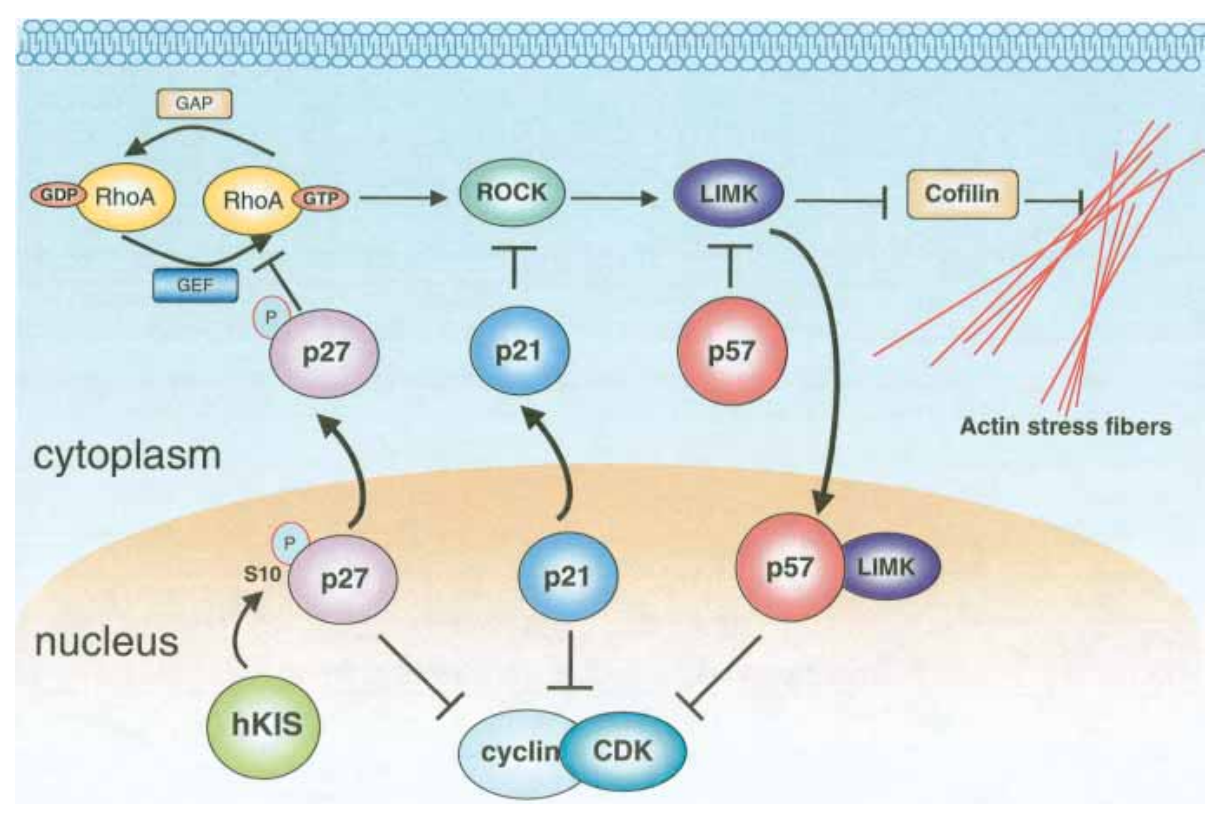

Figure 1. Inhibition of the Rho pathway by the Cip/Kip family members leads to reorganization of the actin stress fiber filaments and promotion of cell migration. In addition to their role as cyclin-CDK inhibitors, members of the Cip/Kip family (p21, p27, p57) regulate actin dynamics through inhibition of the Rho-ROCK-LIMK pathway. Rho GTPases work as molecular switches that cycle between inactive GDP-bound and active GTP-bound states. GTPase-activating proteins (GAPs) promote the inactive state by enhancing the rate of intrinsic GTPase activity of nucleotide hydrolysis. The active GTP-bound state is promoted by guanine-nucleotide exchange factors (GEFs) that induce the release of bound GDP and facilitate GTP binding. Upon stimulation, RhoA is activated by GEFs, and then GTP-bound RhoA activates ROCKs to phosphorylate one of its substrate LIMKs. By doing so, ROCK1 enhances the ability of LIMKs to phosphorylate cofilin, an actin-depolymerizing protein. This phosphorylation inhibits the activity of cofilin. Phosphorylation of LIMKs by ROCKs inhibits disassembly of actin filaments and thereby leads to an increase in stress fibers. Besson et al. (2004) showed that $\mathrm{p} 27^{\mathrm{kip} 1}$ inhibits activation of RhoA by the GEFs. To exert this function, $\mathrm{p} 27^{\mathrm{kip} 1}$ needs to relocalize to the cytoplasm via Ser 10 phosphorylation. Cytoplasmic $\mathrm{p} 21^{\text {cip } 1}$ can inhibit ROCK activity; however, the mechanism underlying $\mathrm{p} 21^{\text {cip } 1}$ export to the cytoplasm is currently unknown. p5 $7^{\text {kip } 2}$ inhibits the function of LIMK by sequestering it in the cytoplasm, away from its substrate cofilin. 
wild-type cells, p2 $7^{\text {kip } 1}$-deficient cells had a significantly higher level of active GTP-bound RhoA and an increased level of phospho-cofilin. Furthermore, inhibition of ROCK activity by a small molecule (Y27632) rescued the migration defect of $\mathrm{p} 27^{\mathrm{kip} 1}$-deficient cells, further solidifying a direct role for Rho inhibition of cell migration in p2 $7^{\text {kip } 1 \text {-deficient cells. }}$

Thus, the migration defect observed in p $27^{\mathrm{kip} 1}$-deficient cells is due to a higher level of activation of the RhoA pathway. Could p2 $7^{\text {kip } 1}$ be directly involved in the regulation of RhoA activity? As it turns out, Besson et al. (2004) showed that $27^{\text {kip } 1}$ binds to RhoA in vitro, suggesting a direct interaction. Likewise, co-immunoprecipitation experiments in HEK $293 \mathrm{~T}$ cells showed that p $27^{\mathrm{kip} 1}$ could interact with both the active and inactive forms of Rho. As these experiments relied on overexpression of both p27 $7^{\text {kip } 1}$ and RhoA, we will need confirmation of these direct interactions by physiologic protein levels. Interestingly, only the C-terminal half of p27 $7^{\mathrm{kip} 1}$ is responsible for the interaction with RhoA, again reaffirming that this cell migration function is independent of binding to cyclin-CDKs. Exactly how does p $27^{\mathrm{kip} 1}$ inhibit RhoA activation? p2 $7^{\mathrm{kip} 1}$ could inhibit Rho activity by preventing GTP loading by guanine-nucleotide exchange factors (GEFs) or by inhibiting the interaction with its effectors, for example ROCK. To answer this question, Besson et al. (2004) tested the capacity of p $27^{\text {kip } 1}$ to inhibit wild-type RhoA or constitutively active RhoA mutant (RhoA-63L; always bound to its effector) and found that $\mathrm{p} 27^{\mathrm{kip} 1}$ could only inhibit the activation of wild-type RhoA, suggesting that $\mathrm{p} 27^{\mathrm{kip} 1}$ does not interfere with RhoA binding to its effectors. Consistent with this, $\mathrm{p} 27^{\mathrm{kip} 1}$ had the ability to inhibit the activation of RhoA by two Rho-specific GEFs, p115-RhoGEF and Lbc. Taken together, these observations indicated that p2 $7^{\text {kip } 1}$ interferes with the interaction of RhoA with its GEFs and thereby interferes with RhoA activation. Thus, Besson et al. (2004) fit the pieces together and show that loss of p27 leads to the observed phenotype of decreased cell motility due to increased Rho activity.

However, there are several unanswered questions. What is the signaling event that induces $\mathrm{p} 27^{\mathrm{Kip} 1}$ to interact with and inhibit RhoA in the cytoplasm? Previous work showed that induction of scattering in hepatocellular carcinoma cells through HGF and Met receptor signaling correlated with phosphorylation of $\mathrm{p} 27^{\mathrm{Kip} 1}$ on Ser 10 and relocalization to the cytoplasm (McAllister et al. 2003). hKIS is the major kinase phosphorylating p2 $7^{\text {Kip1 }}$ on Ser 10 and mediating its nuclear export (Boehm et al. 2002). It will be of interest to determine whether hKIS activity is necessary for the interaction of $\mathrm{p} 27^{\mathrm{Kip} 1}$ with RhoA. It was recently shown that $\mathrm{p} 21^{\mathrm{Cip} 1}$ can also act as an inhibitor of ROCK (Tanaka et al. 2002). Cytoplasmic p $21^{\text {Cip } 1}$ was associated with neural differentiation, neurite outgrowth, and suppression of actin stress fibers in NIH 3T3 fibroblasts. During osteoblast differentiation, cytoplasmic p5 $7^{\mathrm{Kip} 2}$ was found to inhibit LIMK by translocating and sequestering it in the nucleus (Yokoo et al. 2003). The interaction of $\mathrm{p} 57^{\text {Kip2 }}$ and LIMK also correlated with reorganization of actin filaments.
Interestingly, cytoplasmic localization of $\mathrm{p} 27^{\mathrm{Kip} 1}$ has also been associated with the differentiation process of normal myeloid cells (Yaroslavskiy et al. 1999). However, it remains to be determined whether in the course of myeloid differentiation, cytoplasmic $\mathrm{p} 27^{\mathrm{Kip} 1}$ is involved in regulating actin dynamics through the Rho pathway.

The physiologic relevance of the $\mathrm{p} 27^{\mathrm{Kip} 1}-\mathrm{RhoA}$ link also remains to be determined. $\mathrm{p} 27^{\mathrm{Kip} 1}$-deficient mice do not display any obvious migration defect-related phenotype (Fero et al. 1996; Kiyokawa et al. 1996; Nakayama et al. 1996). However, this could be due in part to compensation by $\mathrm{p} 21^{\mathrm{Cip} 1}$ and/or $\mathrm{p} 57^{\mathrm{Kip} 2}$. The analogy between $\mathrm{p} 27^{\mathrm{Kip} 1}$ and the yeast Farl is very interesting (McAllister et al. 2003). Farlp is the yeast cell-cycle inhibitor homo$\log$ that upon $\alpha$-factor pheromone signaling mediates both $\mathrm{G}_{1}$ cell-cycle arrest and bud formation that requires polarization of the actin cytoskeleton toward the opposite mating partner (O'Shea and Herskowitz 2000). Farlp sequesters the Cdc24p GEF that activates the small GTPase Cdc42p in the nucleus. Activation of the pheromone response pathway leads to phosphorylation of Farlp, nuclear export of the Farlp-Cdc24p complex into the cytoplasm, and targeting Cdc24p to the polarity site through its association with G $\beta \gamma$. Given their functionally analogous roles, it is possible that $27^{\mathrm{kip} 1}$ acts in a similar fashion. Besson et al. (2004) did not rule out the possibility that $\mathrm{p} 27^{\mathrm{kip} 1}$ could bind to and sequester a specific Rho-GEF to inhibit activation of RhoA. Although much remains to be learned about this novel link, these new observations highlight the importance of the members of the Cip/Kip family in actin dynamics regulation.

Due to its growth-inhibitory function, $\mathrm{p} 27^{\mathrm{kip} 1}$ is considered a tumor suppressor, and $\mathrm{p} 27^{\mathrm{kip} 1}$-deficient mice are predisposed to the development of spontaneous tumors (Fero et al. 1996; Kiyokawa et al. 1996; Nakayama et al. 1996). In humans, decreased p $27^{\mathrm{kip} 1}$ levels have been correlated with tumor aggressiveness and poor patient survival (Alkarain and Slingerland 2004). Interestingly in light of the observations discussed here, a subset of breast, thyroid, esophagus, and colon carcinomas contain normal levels of p2 $7^{\text {kip } 1}$, but $\mathrm{p} 27^{\mathrm{kip} 1}$ is found in the cytoplasm (Doki et al. 1997; Fredersdorf et al. 1997; Sgambato et al. 1997; Fiorentino et al. 2000). Indeed, cytoplasmic sequestration of $\mathrm{p} 27^{\mathrm{kip} 1}$ is considered a poor prognostic indicator (Slingerland and Pagano 2000). Oddly, although p2 $7^{\mathrm{kip} 1}$ is characterized as a tumor suppressor, inactivating point mutations with loss of heterozygosity are almost never observed in human cancer (Kawamata et al. 1995; Ponce-Castaneda et al. 1995; Ferrando et al. 1996; Alessandrini et al. 1997). Moreover, given what is presented here, a complete elimination of p $27^{\text {kip } 1}$ might not confer as much of a growth advantage to tumor cells as would p2 $7^{\mathrm{kip} 1}$ relocalization from the nucleus and to the cytoplasm. A distinguishing feature of malignant cells is their capacity to invade surrounding normal tissues and migrate through the blood and lymphatic systems to distant organs. Metastatic tumors are thought to select for both increased invasive growth and 
cell migration. Thus, the cytoplasmic role of $\mathrm{p} 27^{\mathrm{kip} 1}$ in promoting cell migration and the absence of a tumor selection for complete loss of $\mathrm{p} 27^{\mathrm{kip} 1}$ begins to look like a gene living a dual life in cancer, one as a nuclear tumor suppressor and the other as a cytoplasmic metastatic oncogene. Clearly much more work on $\mathrm{p} 27^{\mathrm{kip} 1}$ is required before we connect these two dots.

\section{References}

Alessandrini, A., Chiaur, D.S., and Pagano, M. 1997. Regulation of the cyclin-dependent kinase inhibitor $\mathrm{p} 27$ by degradation and phosphorylation. Leukemia 11: 342-345.

Alkarain, A. and Slingerland, J. 2004. Deregulation of p27 by oncogenic signaling and its prognostic significance in breast cancer. Breast Cancer Res. 6: 13-21.

Besson, A., Gurian-West, M., Schmidt, A., Hall, A., and Roberts, J.M. 2004. p2 $7^{\mathrm{kip} 1}$ modulates cell migration through the regulation of RhoA activation. Genes \& Dev. (this issue).

Boehm, M., Yoshimoto, T., Crook, M.F., Nallamshetty, S., True, A., Nabel, G.J., and Nabel, E.G. 2002. A growth factordependent nuclear kinase phosphorylates p27(Kip1) and regulates cell cycle progression. EMBO I. 21: 3390-3401.

Carrano, A.C., Eytan, E., Hershko, A., and Pagano, M. 1999. SKP2 is required for ubiquitin-mediated degradation of the CDK inhibitor p27. Nat. Cell Biol. 1: 193-199.

Coqueret, O. 2003. New roles for p21 and p27 cell-cycle inhibitors: A function for each cell compartment? Trends Cell Biol. 13: 65-70.

Doki, Y., Imoto, M., Han, E.K., Sgambato, A., and Weinstein, I.B. 1997. Increased expression of the p27KIP1 protein in human esophageal cancer cell lines that over-express cyclin D1. Carcinogenesis. 18: 1139-1148.

el-Deiry, W.S., Tokino, T., Velculescu, V.E., Levy, D.B., Parsons, R., Trent, J.M., Lin, D., Mercer, W.E., Kinzler, K.W., and Vogelstein, B. 1993. WAF1, a potential mediator of p53 tumor suppression. Cell 75: 817-825.

Fero, M.L., Rivkin, M., Tasch, M., Porter, P., Carow, C.E., Firpo, E., Polyak, K., Tsai, L.H., Broudy, V., Perlmutter, R.M., et al. 1996. A syndrome of multiorgan hyperplasia with features of gigantism, tumorigenesis, and female sterility in p27(Kip1)deficient mice. Cell 85: 733-744.

Ferrando, A.A., Balbin, M., Pendas, A.M., Vizoso, F., Velasco, G., and Lopez-Otin, C. 1996. Mutational analysis of the human cyclin-dependent kinase inhibitor p27kip1 in primary breast carcinomas. Hum. Genet. 97: 91-94.

Fiorentino, M., Altimari, A., D'Errico, A., Cukor, B., Barozzi, C., Loda, M., and Grigioni, W.F. 2000. Acquired expression of p27 is a favorable prognostic indicator in patients with hepatocellular carcinoma. Clin. Cancer Res. 6: 3966-3972.

Fredersdorf, S., Burns, J., Milne, A.M., Packham, G., Fallis, L., Gillett, C.E., Royds, J.A., Peston, D., Hall, P.A., Hanby, A.M., et al. 1997. High level expression of p27(kip1) and cyclin D1 in some human breast cancer cells: Inverse correlation between the expression of p27(kip1) and degree of malignancy in human breast and colorectal cancers. Proc. Natl. Acad. Sci. 94: 6380-6385.

Gu, Y., Turck, C.W., and Morgan, D.O. 1993. Inhibition of CDK2 activity in vivo by an associated $20 \mathrm{~K}$ regulatory subunit. Nature 366: 707-710.

Harper, J.W., Adami, G.R., Wei, N., Keyomarsi, K., and Elledge, S.J. 1993. The p21 Cdk-interacting protein Cip1 is a potent inhibitor of $\mathrm{G}_{1}$ cyclin-dependent kinases. Cell 75: 805-816.

Ishida, N., Kitagawa, M., Hatakeyama, S., and Nakayama, K. 2000. Phosphorylation at serine 10 , a major phosphorylation site of $\mathrm{p} 27(\mathrm{Kip} 1)$, increases its protein stability. I. Biol. Chem. 275: 25146-25154.

Kawamata, N., Morosetti, R., Miller, C.W., Park, D., Spirin, K.S., Nakamaki, T., Takeuchi, S., Hatta, Y., Simpson, J., Wilcyznski, S., et al. 1995. Molecular analysis of the cyclindependent kinase inhibitor gene p27/Kip1 in human malignancies. Cancer Res. 55: 2266-2269.

Kiyokawa, H., Kineman, R.D., Manova-Todorova, K.O., Soares, V.C., Hoffman, E.S., Ono, M., Khanam, D., Hayday, A.C., Frohman, L.A., and Koff, A. 1996. Enhanced growth of mice lacking the cyclin-dependent kinase inhibitor function of p27(Kip1). Cell 85: 721-732.

Lee, S. and Helfman, D.M. 2004. Cytoplasmic p21Cip1 is involved in Ras-induced inhibition of the ROCK/LIMK/cofilin pathway. J. Biol. Chem. 279: 1885-1891.

Lee, M.H., Reynisdottir, I., and Massague, J. 1995. Cloning of p57KIP2, a cyclin-dependent kinase inhibitor with unique domain structure and tissue distribution. Genes \& Dev. 9: 639-649.

Liang, J., Zubovitz, J., Petrocelli, T., Kotchetkov, R., Connor, M.K., Han, K., Lee, J.H., Ciarallo, S., Catzavelos, C., Beniston, R., et al. 2002. PKB/Akt phosphorylates p27, impairs nuclear import of p27 and opposes p27-mediated $G_{1}$ arrest. Nat. Med. 8: 1153-1160.

McAllister, S.S., Becker-Hapak, M., Pintucci, G., Pagano, M., and Dowdy, S.F. 2003. Novel p27(kip1) C-terminal scatter domain mediates Rac-dependent cell migration independent of cell cycle arrest functions. Mol. Cell Biol. 23: 216-228.

Moon, S.Y. and Zheng, Y. 2003. Rho GTPase-activating proteins in cell regulation. Trends Cell Biol 13: 13-22.

Murray, A.W. 2004. Recycling the cell cycle: Cyclins revisited. Cell 116: 221-234.

Nagahara, H., Vocero-Akbani, A.M., Snyder, E.L., Ho, A., Latham, D.G., Lissy, N.A., Becker-Hapak, M., Ezhevsky, S.A., and Dowdy, S.F. 1998. Transduction of full-length TAT fusion proteins into mammalian cells: TAT-p27Kip1 induces cell migration. Nat. Med. 4: 1449-1452.

Nakayama, K., Ishida, N., Shirane, M., Inomata, A., Inoue, T., Shishido, N., Horii, I., and Loh, D.Y. 1996. Mice lacking p27(Kip1) display increased body size, multiple organ hyperplasia, retinal dysplasia, and pituitary tumors. Cell 85: 707720.

Nourse, J., Firpo, E., Flanagan, W.M., Coats, S., Polyak, K., Lee, M.H., Massague, J., Crabtree, G.R., and Roberts, J.M. 1994. Interleukin-2-mediated elimination of the p27Kip1 cyclindependent kinase inhibitor prevented by rapamycin. Nature 372: 570-573.

O'Shea, E.K. and Herskowitz, I. 2000. The ins and outs of cellpolarity decisions. Nat. Cell Biol. 2: E39-E41.

Pagano, M., Tam, S.W., Theodoras, A.M., Beer-Romero, P., Del Sal, G., Chau, V., Yew, P.R., Draetta, G.F., and Rolfe, M. 1995. Role of the ubiquitin-proteasome pathway in regulating abundance of the cyclin-dependent kinase inhibitor p27. Science 269: 682-685.

Polyak, K., Kato, J.Y., Solomon, M.J., Sherr, C.J., Massague, J., Roberts, J.M., and Koff, A. 1994. p27Kip1, a cyclin-Cdk inhibitor, links transforming growth factor- $\beta$ and contact inhibition to cell cycle arrest. Genes \& Dev. 8: 9-22.

Ponce-Castaneda, M.V., Lee, M.H., Latres, E., Polyak, K., Lacombe, L., Montgomery, K., Mathew, S., Krauter, K., Sheinfeld, J., Massague, J., et al. 1995. p27Kip1: Chromosomal mapping to $12 \mathrm{p} 12-12 \mathrm{p} 13.1$ and absence of mutations in human tumors. Cancer Res. 55: 1211-1214.

Reynisdottir, I., Polyak, K., Iavarone, A., and Massague, J. 1995. Kip/Cip and Ink4 Cdk inhibitors cooperate to induce cell cycle arrest in response to TGF- $\beta$. Genes \& Dev. 9: 1831-1845. 
Riento, K. and Ridley, A.J. 2003. Rocks: Multifunctional kinases in cell behaviour. Nat. Rev. Mol. Cell Biol. 4: 446-456.

Rodier, G., Montagnoli, A., Di Marcotullio, L., Coulombe, P., Draetta, G.F., Pagano, M., and Meloche, S. 2001. p27 cytoplasmic localization is regulated by phosphorylation on Ser10 and is not a prerequisite for its proteolysis. EMBO $T$. 20: 6672-6682.

Russo, A.A., Jeffrey, P.D., Patten, A.K., Massague, J., and Pavletich, N.P. 1996. Crystal structure of the p27Kip1 cyclindependent-kinase inhibitor bound to the cyclin A-Cdk2 complex. Nature 382: 325-331.

Sgambato, A., Zhang, Y.J., Arber, N., Hibshoosh, H., Doki, Y., Ciaparrone, M., Santella, R.M., Cittadini, A., and Weinstein, I.B. 1997. Deregulated expression of p27(Kip1) in human breast cancers. Clin. Cancer Res. 3: 1879-1887.

Sherr, C.J. and Roberts, J.M. 1999. CDK inhibitors: Positive and negative regulators of $\mathrm{G}_{1}$-phase progression. Genes \& Dev. 13: 1501-1512.

Shin, I., Yakes, F.M., Rojo, F., Shin, N.Y., Bakin, A.V., Baselga, J., and Arteaga, C.L. 2002. PKB/Akt mediates cell-cycle progression by phosphorylation of $\mathrm{p} 27^{\mathrm{Kip} 1}$ at threonine 157 and modulation of its cellular localization. Nat. Med. 8: 11451152 .

Slingerland, J. and Pagano, M. 2000. Regulation of the cdk inhibitor p27 and its deregulation in cancer. J. Cell Physiol. 183: $10-17$.

Slingerland, J.M., Hengst, L., Pan, C.H., Alexander, D., Stampfer, M.R., and Reed, S.I. 1994. A novel inhibitor of cyclin-Cdk activity detected in transforming growth factor$\beta$-arrested epithelial cells. Mol. Cell Biol. 14: 3683-3694.

Sutterluty, H., Chatelain, E., Marti, A., Wirbelauer, C., Senften, M., Muller, U., and Krek, W. 1999. p45SKP2 promotes p27Kip1 degradation and induces S phase in quiescent cells. Nat. Cell Biol. 1: 207-214.

Tanaka, H., Yamashita, T., Asada, M., Mizutani, S., Yoshikawa, H., and Tohyama, M. 2002. Cytoplasmic p21(Cip1/WAF1) regulates neurite remodeling by inhibiting Rho-kinase activity. J. Cell Biol. 158: 321-329.

Toyoshima, H. and Hunter, T. 1994. p27, a novel inhibitor of $G_{1}$ cyclin-Cdk protein kinase activity, is related to p21. Cell 78: $67-74$.

Tsvetkov, L.M., Yeh, K.H., Lee, S.J., Sun, H., and Zhang, H. 1999. p27(Kip1) ubiquitination and degradation is regulated by the SCF(Skp2) complex through phosphorylated Thr187 in p27. Curr. Biol. 9: 661-664.

Viglietto, G., Motti, M.L., Bruni, P., Melillo, R.M., D'Alessio, A., Califano, D., Vinci, F., Chiappetta, G., Tsichlis, P., Bellacosa, A., et al. 2002. Cytoplasmic relocalization and inhibition of the cyclin-dependent kinase inhibitor $\mathrm{p} 27^{\mathrm{kip} 1}$ by PKB/Akt-mediated phosphorylation in breast cancer. Nat. Med. 8: 1136-1144.

Yaroslavskiy, B., Watkins, S., Donnenberg, A.D., Patton, T.J., and Steinman, R.A. 1999. Subcellular and cell-cycle expression profiles of CDK-inhibitors in normal differentiating myeloid cells. Blood 93: 2907-2917.

Yokoo, T., Toyoshima, H., Miura, M., Wang, Y., Iida, K.T., Suzuki, H., Sone, H., Shimano, H., Gotoda, T., Nishimori, S., et al. 2003. p57Kip2 regulates actin dynamics by binding and translocating LIM-kinase 1 to the nucleus. J. Biol. Chem. 278: 52919-52923.

Zeng, Y., Hirano, K., Hirano, M., Nishimura, J., and Kanaide, H. 2000. Minimal requirements for the nuclear localization of p27(Kip1), a cyclin-dependent kinase inhibitor. Biochem. Biophys. Res. Commun. 274: 37-42. 


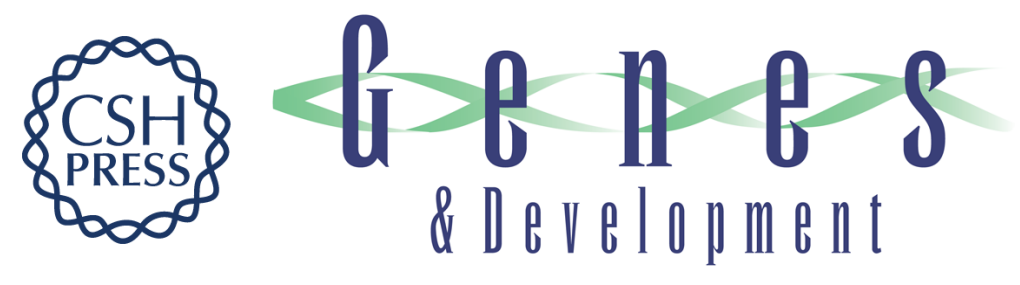

\section{Cip/Kip proteins: more than just CDKs inhibitors}

Catherine Denicourt and Steven F. Dowdy

Genes Dev. 2004, 18:

Access the most recent version at doi:10.1101/gad.1205304

References This article cites 46 articles, 19 of which can be accessed free at: http://genesdev.cshlp.org/content/18/8/851.full.html\#ref-list-1

License

Email Alerting Receive free email alerts when new articles cite this article - sign up in the box at the top Service right corner of the article or click here.

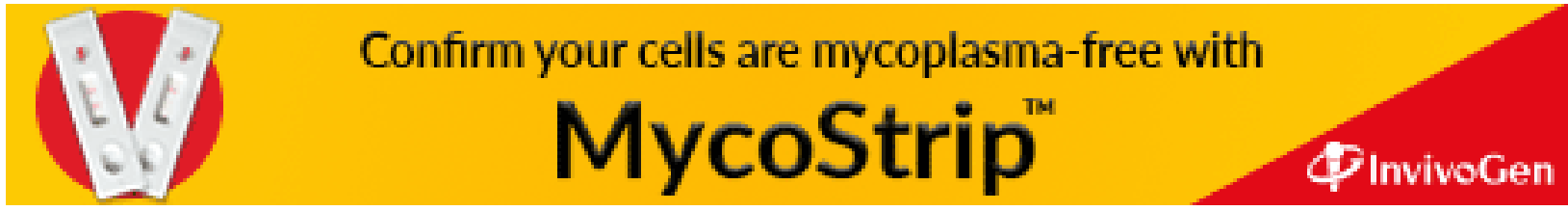

